\title{
The Neoplatonic Logic of Richard Hooker's Generic Division of Law
}

W.J.

TORRANCE KIRBY

Summary: Richard Hooker's theology of Law is rooted in a twofold argument: the systematic appropriation of the neoplatonic structure of argument and an appeal to protestant conceptions of Nature and Grace. This paper offers a close reading of Hooker's Of the Lawes of Ecclesiasticall Politie in an attempt to understand the articulation between Natural and Eternal Laws.

$\mathrm{T}^{\mathrm{n}}$ the first book of his treatise Of the Lawes of Ecclesiasticall Politie, ${ }^{1}$ Richard Hooker constructs a complex generic division of the various forms of Law. His approach to the definition of Law is remarkable for its simultaneous appropriation of a systematic neoplatonic structure of argument and an appeal to orthodox Protestant assumptions with respect to the relation of the orders of Nature and Grace. ${ }^{2}$ At the outset of Book One Hooker offers a brief sketch of his argument in which he provides a useful starting-point for understanding the neoplatonic structure of his system of laws. He begins with an allusion to the polemical occasion of the treatise in the ecclesiological controversies which arose in England as a consequence of the Elizabethan Settlement of 1559 :

Because the point about which wee strive is the qualitie of our lawes, our first entrance hereinto cannot better be made, then with consideration of the nature of lawe in generall, and of that lawe which giveth life unto all the rest, which are commendable just and good, namely the lawe whereby the Eternall himselfe doth worke. Proceeding from hence to the lawe first of nature, then of scripture, we shall have the easier accesse unto those things which come after to be debated, concerning then particular cause and question which wee have in hand (Lawes I.1.3;1:58.11-19). 
By this account, the idea of law is fundamentally threefold. First there is the law "which God hath eternallie purposed himself in all his works to observe" (Lawes 1.3.1;1:63.7). This Eternal Law is the "highest welspring and fountaine" of all other kinds of law. While there is a great variety of derivative forms of law, they are contained, as it were, within two principal kinds: the Law of nature and the revealed Law of scripture. The latter is often referred to by Hooker as the Divine Law, which is not to be confused with Eternal Law. These three summa genera - Eternal Law, Natural Law and Divine Law - together constitute a comprehensive division of the "kinds" of law. On account of the subordination the two derivative summa genera to the one Eternal Law, there is a sense in which Law, viewed from the standpoint of its divine originative principle, is simply one. This apparent ambiguity of the simultaneous unity and multiplicity of law lies at the very heart of Hooker's neoplatonic vision of the procession of the dialectical division of the manifold forms of law out of the one Eternal Law. ${ }^{3}$

\section{The Neoplatonic Structure of Hooker's Discourse}

The starting-point ( $\dot{\alpha} \rho \chi \eta \dot{\eta})$ of Hooker's logic of generic division is classically neoplatonic. The exposition begins properly with God himself, that is God understood as "the One." Hooker states most emphatically that "God is one, or rather verie Onenesse, and meere unitie, having nothing but it selfe in it selfe, and not consisting (as all things do besides God) of many things." 4 In the neoplatonic cosmology, both pagan and Christian, the One is the highest principle, the supreme source of all that is, of all essences and existences, of intellect and of intelligibility, and also of all order in the world. Given the political orientation of his theology, Hooker's emphasis naturally falls on the interpretation of the One as the source of cosmic order. Thus he proceeds to identify the Eternal Law with God himself whose very being is a law to his own divine operation. ${ }^{5}$ His aim in the discourse of Book I is to show "in what maner as every good and perfect gift, so this very gift of good and perfect lawes is derived from the father of lightes" (Lawes I.16.1; $1: 135.11-13)$. Just as neoplatonic cosmology accounts for the genesis of the world by means of a downward procession or emanation from the One, so also Hooker derives a diverse hierarchy of laws from the one Eternal Law. $\mathrm{He}$ adheres closely to the logic of procession whereby the originative principle of Law remains simple in itself while, proceeding out of itself, it too generates manifold derivative forms, and thus is the source of both unity and continuity in the entire system of laws. ${ }^{6}$ 
The unity of the system of laws is expressed through a twofold motion. First there is a downward procession of generation in which the multiple forms of Law come to be out of the One. This is balanced by an upward "return" whereby all derivative forms are gathered up into the original divine unity. Hooker's two derivative summa genera, namely the Natural Law and the revealed Law of Scripture, represent these two principal directions of the cosmic procession. In the circular process of emanation and return, Hooker places his argument in a theological tradition which harks back to the early centuries of the Christian era. Even before this pattern of processio et reditus was taken up by Christian theologians, Plotinus argued that the One is the terminus of all striving in the world because it is the originative first principle. ${ }^{7}$ Similarly for Hooker the creation of the world is an "outward procession" or exitus from the divine unity. The Natural Law is God's means of preserving the order of the world once created; it is effectively the Eternal Law as kept by all creatures. The complete action of return, on the other hand, is accomplished through the redemptive operation of divine self-revelation in the written word of the Scriptures. This Divine Law is God's chosen means of restoring a fallen creation to unity with himself. Metaphysically considered, the purpose of the discourse has in fact two objects in view: first to demonstrate the derivation of the many from the One and secondly to show also the reintegration of the many into the One.

The procession and return of the manifold forms of Law comprised by these summa genera is accomplished hierarchically according to the lex divinatis, the so-called Law of divinity: 8

For order is a graduall disposition. The whole world consisting of partes so manie so different is by this only thing upheld, he which framed them hath sett them in order. Yea the very deitie it self both keepeth and requireth for ever this to be kept as a law, that wheresoever there is a coagmentation of many, the lowest be knitt to the highest by that which being interjacent may cause each to cleave unto other and so all to continue one.

By this neoplatonic Law of procession, the derivative forms of Law in all their complexity remain within the primal form of the Eternal Law, and it continues to be in them without the loss of its own original simplicity. It is the simultaneous procession of the many from the One and the remaining of the many within the One which constitutes the continuity of the cosmic order. ${ }^{10}$ The "order of procession" which culminates in the creation of man, who is the very image of God (Lawes I.7.2; I:77.20), is also broken by him. Owing to man's wilful rejection of the order of creation, the Natural Law by itself is no longer sufficient to secure the unity of the cosmos under God 
(Lawes I.11.5,6;1:118.11-18). While fallen humanities continues to possess a natural desire to be happy (Lawes I.11.4;1:114.8-10) and thus to be reunited with the Eternal source of order, on account of original sin man is "inwardly obstinate, rebellious and averse from all obedience unto the sacred lawes of his nature ... in regard of his depraved mind little better then a wild beast" (Lawes I.10.1;1:96.26-29). Thus observance of the Natural Law is no longer effectual in preserving the original, divinely constituted order. Nonetheless "it is an axiome of nature that naturall desire cannot utterly be frustrate," says Hooker, citing Aristotle. ${ }^{11}$ While nature requires a "more divine perfection," the means whereby this perfection is attained must be supernatural. ${ }^{12}$ A complete restoration of the order is provided directly by God himself in the divine act of Redemption "in himselfe prepared before all worldes." The redemption is a reditus or "return" to God of all creation by "a way mysticall and supernaturall" (Lawes I.11.6;1:118.15,22). The Divine Law revealed in Scripture is God's chosen means of completing a circular mediation of his own "externall working," the purpose of which is "the exercise of his most glorious and most abundant vertue: Which abundance doth shew it selfe in varietie, and for that cause this varietie is oftentimes in scripture exprest by the name of riches. The Lord hath made all things for his owne sake" (Lawes I.2.4;1:61.6-10). The works of both creation and redemption are linked to God's own Trinitarian self-reflection. All things proceed from and return to God by the Divine Word. The utterance of the Word brings the world into being (Lawes I.3.2;1:64.19). The divine work of redemption "God in himselfe prepared before all worldes" (Lawes I.11.6;1:118.23). God is thus an end to himself in the process of both exitus and reditus. The seemingly endless, immeasurable diversity of life in its many forms is stabilised and contained by an order which is nothing less than the divine self-identity. Through the working of creation and redemption, the order of all things both originates and culminates in the one Eternal Law, hence the circular structure of this mediating process. Looked at another way, the Natural Law and the Divine Law are the two most essential moments in the self-mediating operation of the one Eternal Law. In this process of going out from and returning to God who is "the Eternal himselfe," nothing that is made can be said to fall outside the original order established in the one Eternal Law. In this sense Hooker's threefold division of the idea of Law is altogether comprehensive. 


\section{The First and Second Eternal Laws}

If we will give judgement of the lawes under which wee live, first let that law eternall be alwayes before our eyes, as being the principall force and moment to breede in religious mindes a dutifull estimation of all lawes, the use and benefite whereof we see; because there can be no doubt but that lawes apparently good, are (as it were) thinges copied out of the very tables of that high everlasting law, even as the booke of that law hath sayd concerning it selfe, By me Kinges raigne, and by me Princes decree justice (Lawes I.16.2;1:136.4-11).

The Eternal Law can be viewed from two principal standpoints according to the distinction between the internal and the external operations of God. The internal operations are themselves distinguishable into natural and necessary operations of the divine life, on the one hand, and God's voluntary works, on the other. The "necessary" internal operations have to do with the life of the Godhead as a Trinity of three persons in one eternal, divine substance. These workings are so intimately tied to the divine essence as to be above the power of the divine will. The "voluntary" internal operations, on the other hand, have to do with "that law eternall which God himself hath made to himselfe, and therby worketh all things wherof he is the cause and author." In a sense the latter looks towards the divine works which are ad extra, i.e. which fall outside the simple divine life, though these works are viewed as being contained within the will of their author. The Eternal Law as it governs the creation can also be viewed externally as the divine purpose "set downe as expedient to be kept by all his creatures according to the severall conditions wherwith he hath indued them" (Lawes I.13.1;1:63.9). In the latter case, the operation of God ad extra is viewed from the standpoint of the creatures rather than the Creator. On the basis of these two standpoints Hooker distinguishes a first and second Eternal Law.

In the autograph manuscript of his Notes toward a Fragment on Predestination, Hooker observes that God's external operation is twofold: creation and government. ${ }^{13}$ Government naturally presupposes creation. The second Eternal Law is all about the government of God and in this sense corresponds more closely than the first Eternal Law to the teleological definition of Eternal Law in Question 93 of Aquinas's Summa. ${ }^{14}$ The chief difference between the first and second forms of the Eternal Law is therefore to be discerned in the relations which obtain among the worker, the law of the work, and the actual work done. In the case of the first Eternal Law, or "creatio," they remain coequal since God establishes the order of his own voluntary working. In the second Eternal Law, or "gubernatio," there is a 
necessary hierarchical subordination of the creaturely work to the Creator lawgiver who both makes and is, as the divine $\Lambda$ oyos, the law of making. ${ }^{15}$ Hooker's remarks on the first Eternal Law are thus more properly reminiscent of the doctrine of God and Logos theology in the prima pars of the Summa Theologiae of Aquinas. ${ }^{16}$

With this important theological distinction clarified, Hooker embarks upon a more specific division of the various kinds of Law with a general, teleological definition of Law itself as his point of departure:

All things that are have some operation not violent or casual. Neither doth any thing ever begin to exercise the same without some foreconceaved ende for which it worketh.... That which doth assigne unto each thing the kinde, that which doth moderate the force and power, that which doth appoint the forme and measure of working, the same we tearme a Lawe. ${ }^{17}$

In this account, law is represented as absolutely fundamental to everything that is since everything in nature is governed one way or another by law (Lawes I.2.2;1:58.33). The Eternal Law governs both the internal operations of the divine life and also the external divine works of creation and redemption of the world. God in himself is subject to law in the sense that "the beinge of God is a kind of law to his working: far that perfection which God is, geveth perfection to that he doth" (Lawes I.2.2;1:59.5-6). That is to say, the divine operations are subject to the internal necessity of the divine nature. As an "intellectual worker" God governs himself, is indeed a law to himself (Lawes I.2.3;1:60.8). In him law and activity are one and the same, for God is "verie Onenesse." Yet in the unity of his substance God is understood to be both the "worker" and the "lawe" whereby his works are wrought. In the case of all other forms these "moments" are ontologically separate. In God himself, the mediation of the moments is dependent upon a Trinitarian understanding of the divine nature. ${ }^{18}$ There are three elements to be considered in the divine operation: the worker himself, the pattern of the work, and the actual act of working. According to Hooker's orthodox Trinitarian logic, these three continue to be undivided in the unity of the divine substance, for God, by the necessity of his very own nature, can have nothing in himself but himself. In the language of the Athanasian Creed, all three moments "are coeternal together and coequal." 19 Hooker maintains that the internal operations of the Godhead as a Trinity of distinct persons within the unity of one divine substance are the supreme expression of law. At this highest level there is no externality of ruler, rule and ruling. On this account the generation of the Son and the procession of the Spirit are the 
most perfect operations expressive of the first Eternal Law. It is essential to Trinitarian orthodoxy that these operations are involuntary for they belong by internal necessity to the triune nature of the Godhead. Although Hooker is reluctant to wade more deeply into these internal operations of the Godhead - on this subject "our safest eloquence is silence" - nonetheless he is clearly intent on establishing the source of law at the highest possible ontological level.

For Hooker also the pagan philosophers were able to attain to a knowledge of the nature of God and of his Law. ${ }^{20}$ Hooker cites the example of Plato's demiurge who brings the visible world into being according to a plan or pattern $(\pi \alpha \rho \alpha \delta \epsilon i \gamma \mu \alpha)$ which is its own thought. ${ }^{21}$ In this philosopher's account of creation, the visible world is a "moving image of eternity." The divine worker is manifested through his work. Mercurius Trismegistus, who was thought in the sixteenth century to be an ancient Egyptian teacher of universal philosophy, maintained that the world was made not with hands, but by Reason $(\lambda \circ \gamma \omega){ }^{22}$ Cicero too defines Law as "something eternal which rules the whole universe by its wisdom in command and prohibition." 23 In each of Hooker's references to pagan authors the same principle is revealed: order or Law is a divine, and therefore self-mediating rational principle. "Neither have they otherwise spoken of their cause, than as an Agent, which knowing what and why it worketh, observeth in working a most exact order or lawe." Thus at the very highest level of both pagan and Christian theology, Law is manifest as eternal, self-originating, self-mediating principle in which there is a distinction of the agent, the principle or rule of action, and the action or operation itself. Quite remarkably, Hooker seems to suggest in this passage that a Logos theology can be discerned in the pagan understanding of Law as the divine first principle and perhaps also, by implication, an adumbration of the Christian doctrine of the Trinity. Homer, Plato, the Stoics, and no less an authority than Thrice-great Hermes are all enlisted in support of the proposition implicit in these expressions of Logos theology, namely that God is Law. ${ }^{24}$ From the standpoint of the natural knowledge of God, the conclusion reached is much the same: the life of God is the very substance of Law. Hooker identifies the light of reason with the divine Logos of the Prologue to John's Gospel. Here the "word" of God in scripture is twinned with the "word" of rational human discourse in and through their common source, the eternal divine "Word." 25 God the "light of light" is the author of both the light of reason and the revealed light of the 
scriptures (Lawes III.8.9; 1:226.11-14). ${ }^{26}$ God, the author of nature, speaks through nature whose voice is His instrument. ${ }^{27}$

Knowledge of the Eternal Law as a divine principle of self-imposed order is, as we have seen, variously accessible by supernatual revelation, philosophical reflection, and through the poetical inspiration of the Muses which may lie somewhere between the other two. Looked at more systematically, Hooker presents the knowledge of the Eternal Law according to the duplex cognitio dei. It is important to qualify the degree of knowledge. For Hooker the substance of the Eternal Law is altogether beyond our grasp. At this highest level of the inquiry into the essence of Law, theology must be apophatic, for "dangerous it were for the feeble braine of man to wade farre into the doings of the most High, whome although to knowe be life, and joy to make mention of his name: yet our soundest knowledge is to know that we know him not as in deed he is, neither can know him ... his glory is inexplicable, his greatnes above our capacitie to reach" (Lawes I.2.2;1:59.12-19). Unlike the book of Nature or the book of Scripture, the first Eternal Law is likened to a book which "we are neither able nor worthie to open and looke into." 28 Nevertheless, Hooker maintains that we are able to know the universality, the eternity, and the immutability of this law. Scripture reveals that the God's hidden counsel is a "thing unchangeable" (Heb.6:17).

God himself is Law, both to himself and to all other things besides. The first Eternal Law comprises both the inward and the outward actions of God. As we have already observed, even in his external working God continues to be an end to himself for the end of this external labour is nothing other than "the exercise of his most glorious and most abundant vertue." 29 In the outward exercise of his power or "vertue," God works voluntarily, though now under a self-imposed law. This law is manifest in every voluntary act of the creator. Thus, underlying the great act of creation there is a self-mediated action of the lawgiver who wills to act according to a rational purpose. ${ }^{30} \mathrm{As}$ distinct from the purely internal operations discussed above, there is necessarily a separation of the worker and the work in the outward acts of God. In the outward acts there is a disproportion between the law of operation and the operation itself; the former is infinite while the latter is finite. ${ }^{31}$ Thus an externality of law and the operation ruled by it comes about in "everie acte proceeding externally from God." The worker and the rule of operation continue to be coequal. Reason and Will are perfectly united in the outward expression of the Eternal Law. ${ }^{32}$ The Eternal Law, however, imposes no 
limitation on the freedom of the divine will. The law whereby the world is created and governed is voluntarily self-imposed; the first Eternal Law is "that order which God before all ages hath set down with himselfe, for himselfe to do all things by" (Lawes I.2.6;1:63.2).

Hooker states that this Logos theology is not the customary account given of the Eternal Law. ${ }^{33}$ The more usual definition of Eternal Law is, for example, the one formulated by Augustine in De Libero Arbitrio and cited by Aquinas in the Summa Theologiae: "The Eternal Law is the supreme exemplar (summa ratio) to which we must always conform." 34 Aquinas comments on this definition by observing that the divine plan which directs every creature to its appointed end has the nature of a law just as the model or pattern in the divine wisdom through which all things were created has the nature of an exemplar. "Accordingly, the Eternal Law is nothing other than the idea in Divine wisdom inasmuch as it directs all acts and movements." 35 The emphasis here is upon the teleological ordering of the creation to its proper end. Augustine may well have obtained his definition from Cicero's treatise on law where he too defines law as "the highest reason implanted in nature (ratio summa insita in natura)."36

The great variety of laws which make up the grand scheme of Hooker's generic division are all gathered together under the governance of the second Eternal Law which "receyveth according unto the different kinds of things which are subject unto it different and sundry kinds of names." 37 The second Eternal Law comprises the law of irrational natural agents, angelic law, the law of reason, human positive law, the law of nations, as well as the revealed Law of scripture. All of these forms of law are distinct expressions of the one and undivided "gubernatio Dei." In the Notes toward a Fragment on Predestination, Hooker goes on to distinguish between various species of this gubernatio:

Government is that work of God whereby he sustains created things and disposes all things to the end which he naturally chooses, that is the greatest good which, given the law of creation, can be elicited. For, given the law of creation $<<$ is the rule of all $>>$ that creation be violated through those things which follow from creation. So God does nothing by his government which offends against that which he has framed and ratified by the very act of creation. The government of God is: general over all; special over rational creatures. There are two forms of government: that which would have been, had free creation not lost its way; that which is now when it has lost its way. ${ }^{38}$

This passage reveals the theological principle underlying the generic division of laws. On one side are laws governing the order of unfallen Creation. Among these Hooker includes the law of nature insofar as it 
governs irrational and non-voluntary natural agents. This again is a significant departure from the usual, more restricted sense of Natural Law as an "intellectual habit" of the soul, that is to say the summa ratio as it is present and known to rational creatures. ${ }^{39}$ The "law coelestial" is natural law as observed by unfallen rational creatures, namely the angels. The "law of reason" is Natural Law for rational human creatures.

In order to be properly understood, the Natural Law must be considered in relation to both its originative source, the Eternal Law, and its twin, as it were, the revealed Law of scripture. Scripture attests to the common source of these summa genera of Law in God himself: "Doth not the Apostle term the Law of Nature even as the Evangelist doth the Law of Scripture, ' $\delta \imath \kappa \alpha i \omega \mu \alpha$ tou $\theta \in o u$, Gods own righteous ordinance." 40 These two primary derivative forms of Law together account for both the "outward procession" of the entire created order from and its final redemptive return by a "way mystical and supernaturall" to the original divine unity. ${ }^{41}$ The Eternal Law is thus both the starting point ( $\dot{\alpha} \rho \chi \eta \dot{\eta})$ and the goal ( $\tau \dot{\varepsilon} \lambda \circ \varsigma)$ of all order. Natural Law and Divine Law represent for Hooker the two motions of cosmic procession and return and in this way the two summa genera constitute a comprehensive division of the idea of Law. ${ }^{42}$ The Natural Law is God's means of preserving the order of the world once created; it is effectively the Eternal Law as kept by all creatures. Had Adam continued in his unfallen state, the Natural Law would have sufficed to bring him to "the reward of blisse." In the Divine Law of scripture God reveals his chosen means of restoring fallen creation to unity with himself (Lawes I.11.5,6;1:115.25-119.23). This revealed way of redemption is also an expression of the one Eternal Law and is described by Hooker as prepared by God in himself before all worlds (Lawes I.11.6;1:118.23). We shall seek to demonstrate that Hooker's conservative neoplatonic presentation of this twofold division of the Eternal Law manifests in content the essentially Lutheran structure of the two realms of Creation and Redemption. ${ }^{43}$

By the unaided illumination of natural reason, it is possible to distinguish true from false, good from evil, and consequently a certain degree of knowledge of the divine will itself is attainable without the help of supernatural revelation. This natural knowledge of God consequently leads to a natural practical wisdom. To know theologically what human nature is and where it stands in the larger order of creation is the starting point for reflection upon the principles of human action (Lawes I.8.6;1:86.25-29). In this context Hooker is able to compare the virtue of voluntary obedience to 
the Natural Law on the part of rational creatures with the external beauty of the hierarchically ordered cosmos (Lawes I.8.9; 1:89.31-90.11). Building upon this argument with respect to the natural knowledge of God, he proceeds to show that one and the same moral Law is taught by Plato, Aristotle, Moses and Christ with respect to our natural duty both towards God and our fellow man (Lawes I.8.7,8;1:87.9-89.2). The second great commandment in Christ's summary of the Law, for example, is grounded in the law of non-contradiction, a law of the rational faculty. Throughout this discussion of the axioms of virtuous action Hooker presupposes that "the mindes even of naturall men, have atteyned to know, not onely that there is a God, but also what power, force, wisedom, and other properties God hath, and how all things depende on him (Lawes I.8.7;1.87.14-17).

Given that rational, free creation has lost its "way" on account of the Fall, it is necessary to the preservation of the created order that there be a special revelation from God in the Divine Law of the Scriptures, both through the Law and the Prophets and through the Gospel of Christ. Finally there is need of positive "humane law" or "such lawes of government as serve to direct even nature depraved to a right end" (Lawes I.10.1;1:96.33). The latter can be further divided into categories of civil, ecclesiastical and international law, of which the latter contains within it the laws of arms and embassage. Special law, for example, governing the authority of general councils of the church can be regarded as a hybrid species of ecclesiastical law and the law of nations. ${ }^{44}$ The subdivision can certainly go a great deal further. The chief point to observe is that the structure of the division is theologically determined by three main distinctions. First there is the twofold character of God's external operation as "Maker and Preserver of all things both visible and invisible." 45 God's work as Creator is distinct from his work as Governor, hence the distinction of the first and second Eternal Laws. Secondly, there is a distinction between God's general government over all creatures and a special government over rational creatures. Out of the latter arises the distinction between the main species of Natural Law. Finally the mode of the special divine government over rational creatures is itself twofold on account of the Fall. The Natural Law is both a law of reason and the pattern for positive human law. Human law serves as a remedy for $\sin .46$ Both positive human law and the Divine Law presuppose the corruption of human nature, so that they are posterior to the laws which suppose a free creation which has not lost its way. It is therefore structurally appropriate that Hooker's discussion of the Divine Law immediately follows upon the 
treatment of positive human law. With the various forms of human law the descent, as it were, from the perfection of the Eternal Law is complete.

Knowledge of the creator, however, is not to be confused with knowledge of the redeemer, yet the complete account of law demands recognition of both species of knowing. Only through the supernatural revelation of the scriptures is it possible to hope for a participation of the divine nature. Scripture alone can reveal the supernatural way of salvation, the final "return" to the original "author fountain cause of justice":

The light of nature is never able to finde out any way of obtayning the reward of blisse, but by performing exactly the duties and workes of righteousnes. From salvation therefore and life all flesh being excluded this way, behold how the wisedom of God hath revealed a way mysticall and supernaturall ... concerning that faith hope and charitie without which there can be no salvation; was there ever any mention made saving only in that lawe which God him selfe hath from heaven revealed? ${ }^{47}$

Only by divine grace can the soul attain to a saving knowledge whereby it might participate in the divine nature and "live as it were the life of God" (Lawes I.11.2;1:112.20). Owing to man's wilfull rejection of the order of creation, the Natural Law by itself is insufficient to secure the unity of the cosmos under God. With a marked Augustinian emphasis Hooker notes that fallen humanity continues to possess a natural desire to be happy (Lawes I.11.4;1:114,8-10), and thus to be reunited with the eternal source of order; yet, on account of original sin, man is "inwardly obstinate, rebellious and averse from all obedience unto the sacred lawes of his nature ... in regard of his depraved mind little better then a wild beast" (Lawes I.10.1;1:96.26-29). Observance of the Natural Law is no longer effectual in preserving the divinely constituted order of creation. According to Aristotle "it is an axiome of nature that naturall desire cannot utterly be frustrate." 48 Reason cannot escape the predicament of desiring both a participation of the divine nature while, at the same time, being constitutionally incapable of finding its way to the consummation of its own deepest longing. ${ }^{49}$ While nature demands a "more divine perfection," the means whereby this perfection is attained cannot themselves be natural. The redemption or mystical "return" to God of all creation can only be by supernatural means. Thus the Divine Law is the means of ensuring that nothing whatsoever in the created order falls outside the divine governance. By this account the cyclic rhythm of processio and reditus from the One and to the One is perfect and complete. 


\section{Notes}

1. All references to Hooker's works are from the authoritative and complete Folger Library Edition of the Works of Richard Hooker, gen. ed. W. Speed Hill, 6 vols. (Cambridge and London: The Belknap Press of Harvard University Press, 1977-1993). All references to this edition (FLE) cite volume, page and line numbers. Citations from Of the Lawes of Ecclesiasticall Politie (Lawes) give book, chapter and section followed by volume, page and line numbers of the Folger edition in brackets.

2. For an important discussion of related questions see W. J. Hankey, "Augustinian Immediacy and Dionysian Mediation in John Colet, Edmund Spenser, Richard Hooker and the Cardinal de Bérulle," to be published in Acts of the 1996 Kolloquium "Augustinus in der Neuzeit. Von Petrarca zum 18. Jhrhundert", ed. Kurt Flasch and Dominique de Courcelles. I am much indebted to Dr. Hankey for his contribution to my thinking on this question.

3. On the concept of the procession of the forms of Law see, for example, I.3.4;1:68.6-8: “. . . the naturall generation and processe of all things receyveth order of proceeding from the setled stabilitie of divine understanding."

4. Lawes I.2.2;1:59, 20-22. This emphasis upon God's simplicity of being is central to neoplatonic thought. The "One" of Plotinus transcends thought and all determinacy, and is the archè from which and to which all multiplicity proceeds. See Plotinus, The Enneads, trans. Stephen McKenna (Burdett, NY: Larson Publications, 1992), III.8, pp. 273-287; V.4, pp. 460-464; VI.9, pp. 698-709. On the importance of the doctrine of the One in the thought of Plotinus, see Elmer O'Brien, ed. The Essential Plotinus: Representative Treatises from the Enneads, 2nd. ed. (Indianapolis: Hackett, 1978, pp. 17-21. For a Christian appropriation of this doctrine see also Pseudo-Dionysius, The Divine Names, in The Complete Works, trans. Colm Luibheid and Paul Rorem (Mahwah, NJ: Paulist Press, 1987), ch. XIII concerning "Perfect" and "One," 977B 1-981B 8, pp. 127-130.

5. Lawes I.2.2;1:59.5: "The being of God is a kinde of lawe to his working: for that perfection which God is, geveth perfection to that he doth." The trinitarian structure of Hooker's thought is already discernible in this preliminary observation concerning the Eternal Law.

6. For further examples of Hooker's employment of the neoplatonic language and logic of "procession," see Lawes I.3.2;1:65.4, I.3.4;1:67.29/1:68.6-8, I.5.2;1:73.5-8. At the latter he states: "Againe sith there can bee no goodnesse desired which proceedeth not from God himselfe, as from the supreme cause of all things; and every effect doth after a sort conteine, at least wise resemble the cause from which it proceedeth: all things in the worlde are saide in some sort to seeke the highest, and to covet more or lesse the participation of God himselfe." The neoplatonic logic of "procession" is aptly summarised by Proclus as follows: "every effect remains in its cause, proceeds from it, and returns to it." The Elements of Theology, ed. E. R. Dodds (Oxford: Clarendon Press, 1963), p. 38.

7. Plotinus, The Enneads, trans. McKenna, III.8.7: "It is certain, also, that as the Firsts exist in vision all other things must be straining towards the same condition; the starting point

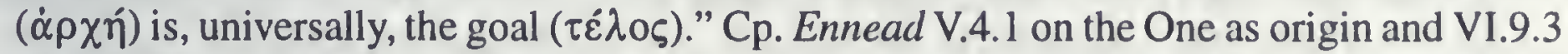
on the One as end. For an instance of the Christian appropriation of this "exitus-reditus" theology see Augustine, Confessions, trans. Henry Chadwick (Oxford: Oxford University Press, 1991), XIII.iv.5. See also Pseudo-Dionysius, CH 1 120B 1 - 120A 2, The Complete Works, p. 145: "Inspired by the father, each procession of the Light spreads itself generously toward us, and in its power to unify, it stirs us by liftin us up. It returns us back to the oneness 
and deifying simplicity of the Father who gathers us in. For, as the sacred Word says, 'from him and to him are all things"' (Rom. 11:36). Compare Lawes I.2.6;1:62.14-20. See Paul Rorem's note 4 on p. 145 of Pseudo-Dionysius, The Complete Works.

8. For a discussion of the scholastic appeal to the Dionysian lex divinitatis see W.J. Hankey, "'Dionysius dixit,' lex divinitatis est ultima per media reducere: Aquinas, Hierocracy and 'augustinisme politique'," in Tommaso d'Aquino: proposte nuove di letture. Festschrift Antonio Tognolo, ed. Ilario Tolomio, Medioevo. Rivista di Storia della Filosofia Medievale, 18 (Padova: Editrice Antenore, 1992), pp. 119-150. The lex divinitatis is the law of the "great chain of being." Hooker mentions the metaphor of the "chain" at $1.11 .1 ; 1: 111.14$ in the context of an Aristotelian teleological defense of the unity of all motion and desire in a "finall cause." Although he does not actually use the term lex divinitatis, Arthur O. Lovejoy defines the law of the chain in his classic study, The Great Chain of Being: A Study of the History of an Idea. The William James Lectures Delivered at Harvard University, 1933 (Cambridge: Harvard University Press, 1936), p. 59: "the conception of the universe as ... composed of an immense, or - by the strict but seldom rigorously applied logic of the principle of continuity - of an infinite, number of links ranging in hierarchical order from the meagerest kind of existents, which barely escape non-existence, through 'every possible' grade up to the ens perfectissimum - or, in a somewhat more orthodox version, to the highest possible kind of creature, between which and the Absolute Being the disparity was assumed to be infinite - everyone of them differing from that immediately above and that immediately below it by the 'least possible' degree of difference."

9. Lawes VIII.2.1; 3:331.19-332.1. In Hooker's autograph manuscript draft of this passage, he cites the Christian neoplatonist Pseudo-Dionysius as his source of information. See FLE 3:494.10-12" "Lex itaque divinitatis est infima per media ad suprema reduci, inquit B. Dionysius. [And so it is a Divine Law, says St. Dionysius, for the lowest things to be led back to the highest by those that are intermediate.]" The translation of "divinitatis" in the FLE Commentary, given here in square brackets, is potentially misleading. Divinitas is to be taken substantively and not as an adjective. Lex divinitatis is more properly "the law of the divine power" and refers to the operation of the Eternal Law in and through the process of exitus and reditus, that is through the law of the chain. Compare The Celestial Hierarchy, in The Complete Works, ed. Luibheid, pp. 156-159, 166-169, and The Ecclesiastical Hierarchy, pp. 233-243. This formulation of the lex divinitatis is Boniface VIII's in the bull Unam Sanctam (1302), incorporated into Extravagantes Communes, 1.8.1 "De Maioritate et Obedientia": "Nam secundum beatum Dionysium, Lex divinitatis est, Infima per media in suprema reduci." See the Corpus Iuris Canonici, ed. P. Lancelotus (Paris, 1587), p. 853; Friedberg, 2:1245. See FLE6(2), p. 1081. See also David Luscombe, "The 'Lex Divinitatis' in the Bull 'Unam Sanctam' of Pope Boniface VIII," in C.N.L. Brooke \& al., eds. Church and Government in the Middle Ages (New York: Cambridge University Press, 1985), pp. 205-221.

10. Compare Pseudo-Dionysius in the Celestial Hierarchy, CH 1 120A 1: "Even though in various ways every divine enlightenment proceeds, out of goodness, toward those provided for, it not only remains simple in itself but also unifies those it enlightens."

11. Lawes I.11.4;1:114.15. Hooker cites the Proemium of Aquinas's commentary on Aristotle's Metaphysics. See Thomas Aquinas, Metaphysicorum Aristotelis expositio in duodecim libros (Turin: Marietti, 1950), p. 6. That nature does nothing in vain is a central doctrine of Aristotle's Physics. See also Commentary, FLE 6(I), 513. 
12. See Lawes I.11.4-6;1:114.8-119.23.

13. Richard Hooker, Notes toward a Fragment on Predestination, Trinity College, Dublin, MS 364, F80v, FLE 4:86.11-17, also printed in Supplement II, FLE 3:527.12-18: "Operatio Dei ad extra est duplex: Creatio. Gubernatio. Gubernatio praesupponit creationem. Non enim gubernatur quod non est."

14. Thomas Aquinas, The Treatise on Law [Summa Theologiae, IaIIae, QQ.90 through 97], edited with Introduction, Latin Text, Translation, and Commentary by R.J. Henle (London: Notre Dame Press, 1993), pp. 204, 205: "Sed contra est quod Augustinus dicit (De Lib.Arb. $\mathrm{i}, 6)$ quod lex aeterna est summa ratio, cui semper obtemperandum est." [Augustine says that the Eternal Law is the supreme exemplar to which we must always conform.] Corpus: "Sicut ratio divinae sapientiae, inquantum per eam cuncta sunt creata, rationem habet artis, vel exemplaris, vel ideae, ita ratio divinae sapientiae moventis omnia ad debitum finem obtinet rationem legis. Et secundum hoc lex aeterna nihil aliud est quam ratio divinae sapientiae, secundum quod est directiva omnium actuum et motionum." [Just as the model in the Divine wisdom through which all things were created has the nature of an art or exemplar or idea, so the plan in the Divine wisdom which moves everything to its proper end has the nature of a law. And, accordingly, the Eternal Law is nothing other than the idea in Divine wisdom inasmuch as it directs all acts and movements.]

15. See Gibbs, "Introduction to Book I," FLE 6 (I), p. 99.

16. See W. J. Hankey, God in Himself: Aquinas' Doctrine of God as Expounded in the Summas Theologiae (Oxford: Oxford University Press, 1987). For an excellent account of Aquinas's employment of the exitus et reditus logic, see pp. 22-35. Hankey maintains against M.-D. Chenu that Christ alone is the via of return in Aquinas's argument. For Chenu, there are two returns in the Thomist theology, a natural one in the Secunda Pars, and one through gracious history: "The transition of IIa to the IIIa Pars is a passage from the order of the necessary to the order of the historical, from an account of structures to the actual story of God's gifts." M.-D. Chenu, Toward Understanding St. Thomas, trans. with authorized corrections and bibliographical additions by A.-M. Landry and D. Hughes (Montreal/Paris: Library of Living Catholic Thought, 1964), p. 315.

17. Lawes $1.2 .1 ; 1: 58.22-29$. This negative definition of law as an "operation not violent or casual" is a restatement of Aristotle's dictum that everything in nature acts for the sake of an end. For Hooker that end or $\tau \in \lambda \circ \zeta$ is nothing but Law. See Aristotle's refutation of the view that chance and spontaneity are "causes" in Physics, 198a5-13 and 198bl0 as well as his explanation that "Nature belongs to the class of causes which act for the sake of something," beginning at 199a3-8. For further discussion of this definition see Arthur Stephen McGrade's Introduction to his edition of Richard Hooker, Of the Laws of Ecclesiastical Polity: Preface, Book I, Book VIII (Cambridge: Cambridge University Press, 1989), pp. $x x-x x$ ii.

18. According to the Articles of Religion, article I, "Of Faith in the Holy Trinity," "there is but one living and true God, everlasting, without body, parts, or passions; of infinite power, wisdom, and goodness; the Maker and Preserver of all things both visible and invisible. And in unity of this Godhead there be three persons, of one substance, power, and eternity; the Father, the Son, and the Holy Ghost." The reference to the two divine names "Maker" and "Preserver" alludes to the duplex operatio dei ad extra, namely creation and governance. See Hooker, Notes toward a Fragment on Predestination, FLE, 4:86.11. 
19. See "The Creed of St. Athanasius, commonly so called," in The Book of Common Prayer (1662), v. 26.

20. Lawes I.2.3;1:59.33-60: "the wise and learned among the verie Heathens themselves, have all acknowledged some first cause, whereupon originallie the being of all things dependeth. Neither have they otherwise spoken of that cause, then as an Agent, which knowing what and why it worketh, observeth in working a most exact order or lawe ... all confesse in the working of that first cause, that counsell is used, reason followed, a way observed, that is to say, constant order and law is kept, wherof it selfe must needs be author unto itselfe."

21. See the Timaeus, 37d, trans. Benjamin Jowett, The Collected Dialogues of Plato, eds. Edith Hamilton and Huntington Cairns (Princeton: Princeton University Press, 1961), p. 1167: "The nature of the ideal being was everlasting, but to bestow this attribute in its fullness upon a creature was impossible. Wherefore [the demiourgos] resolved to have a moving image of eternity, and when he set in order the heaven, he made this image eternal but moving according to number, while eternity itself rests in unity, and this image we call time ... Time and the heaven came into being at the same instant."

22. On Hooker's use of the Hermetica see Wayne Shumaker, The Occult Sciences in the Renaissance: A Study in Intellectual Patterns (Berkeley: University of California Press, 1972), pp. 238-239.

23. Delegibus, 2.6. See Loeb Classical Library Edition, trans. C.W. Keyes (Cambridge: Harvard University Press, 1975), pp. 379-381.

24. Lawes I.2.3;1:60.4-11: 'Thus much is signified by that which Homer mentioneth, $\Delta$ tó $\delta^{\delta}$

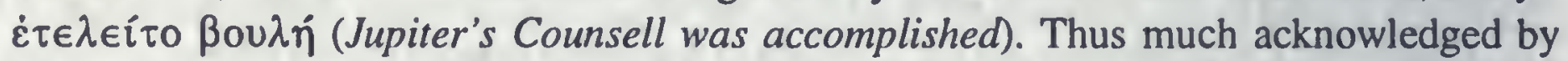

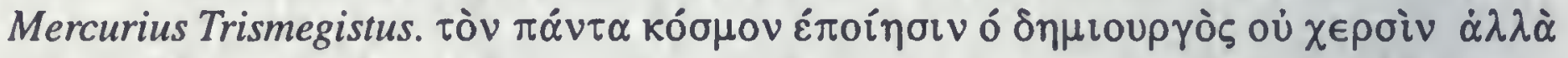
$\lambda o \gamma \omega$ (The creator made the whole world not with hands, but by Reason). Thus much confest by Anaxagoras and Plato, terming the maker of the world an Intellectual worker. Finallie the Stoikes, although imagining the first cause of all things to be fire, held

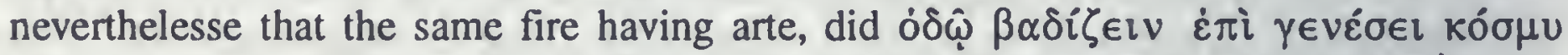
(Proceed by a certaine and a set Waie in the making of the world)." All translations are Hooker's own. In the FLE commentary on Book I, it is observed that Hooker derives his references to Anaxagoras, Plato and the Stoics from the fifth-century Stobaeus's Eclogues. See P.G. Stanwood, "Stobaeus and Classical Borrowing in the Renaissance," Neophilologus, 59 (1975): pp. 141-146.

25. Lawes III.9.3;1:238.25: "The light of naturall understanding wit and reason is from God, he it is which thereby doth illuminate every man entering in the world. If there proceede from us any thing afterwardes corrupt and naught, the mother thereof is our own darknes, neither doth it proceede from any such cause whereof God is the author. He is the author of all that we thinke or doe by vertue of that light, which himself hath given (John 1:5)."

26. See Lawes V.56.2;2:235.25-27: "The Sonne [is] in the father as light out of which it floweth without separation; the father [is] in the Sonne as light in that light which it causeth and leaveth not."

27. Lawes I.8.3;1:84.4 and see also I.3.4;1:67.16-20, 68.18: "Those things which nature is said to do, are by divine arte performed, using nature as an instrument: nor is there any such arte or knowledge divine in nature her selfe working, but in the guide of natures worke." Compare Calvin, Comm. on Hab. 2:6, CO 43.540.1; Commentaries on the Twelve Minor 
Prophets, trans. John Owen, Vol. 4 (Grand Rapids, MI: Eerdmans, 1950), pp. 92-93: "Since some principle of equity and justice remain in the hearts of men, the consent of all nations is, as it were, the voice of nature or the testimony of that equity which is engraven on the hearts of men, and which they can never obliterate. This also is the dictate of nature..." (my italics).

28. Lawes I.2.5;1:62.10. See also Notes on Predestination, FLE 4:85.15: "Scientia divina est liber in quo scripta sunt omnia etiam nomina, quibus nihil magis contingentur evenit." [Divine knowledge is a book in which are written the very names of all men, than which nothing more contingent exists.]

29. "Vertue" has the connotation here of power and strength.

30. Some interpreters of Hooker have argued that his theology is realist as opposed to voluntarist. Yet here it is clear that the divine will is an integral element alongside the divine reason in the doctrine of Eternal Law. See Lee W. Gibbs, "Introduction to Book I," FLE 6(I), pp. 97, 103. See also Peter Munz, The Place of Hooker in the History of Thought (London: Routledge \& Kegan Paul, 1952; repr. New York: Greenwood Press, 1970), p. $140 \mathrm{ff}$ and W. J. Torrance Kirby, Richard Hooker's Doctrine of the Royal Supremacy (Leiden \& New York: E.J. Brill, 1990), pp. 13-15.

31. Lawes I.2.5;1:61.15-18: "Undoubtedly a proper and certaine reason there is of every finite worke of God, in as much as there is a law imposed upon it; which if there were not, it should be infinite even as the worker himselfe is."

32. See Gibbs, "Introduction to Book I," FLE 6(I), 97.

33. Lawes I.3.1;1:63.6-17: "I am not ignorant that by law eternall the learned for the most part do understand the order, not which God hath eternallie purposed himselfe in all his works to observe, but rather that which with himselfe he hath set downe as expedient to be kept by all his creatures, according to the severall conditions wherewith he hath indued them. They who thus are accustomed to speake apply the name of Lawe unto that only rule of working which superior authority imposeth, whereas we somewhat more enlarging the sense thereof, terme any kind of rule or canon whereby actions are framed a law. Now that law which as it is laid up in the bosome of God, they call aeternall, receyveth according unto the different kinds of things which are subject unto it differenct and sundry kinds of names."

34. De Lib. Arb., I.6, cited by Thomas Aquinas, The Treatise on Law [Summa Theologiae, Ia IIae, QQ.90 Through 97], ed. R.J. Henle, p. 204. "Lex aeterna est summa ratio, cui semper obtemperandum est."

35. Treatise on Law, p. 205.

36. De Legibus, 1.4, ed. C.W. Keyes, p. 317.

37. Lawes I.3.1;1:63.16. Compare Thomas Aquinas, Treatise on Law, ed. R. J. Henle, Q.93, art. 1, p. 200: "But things that are diverse in themselves are considered as one according to their ordination to something common. There, the Eternal Law is one, that is the exemplar of this ordination."

38. John Booty's translation of Hooker's Latin notes in FLE 4:86.28-87.12: "Gubernatio est ea Dei operatio qua res creatas sustentat disponitque omnia in finem ab ipso naturaliter expetitum id est maximum bonum quod posita creationis lege potest elici. Etenim posita 
creationis lex <est regula omnium> per ea quae secuta sunt creationem violare non decuit. Nihil itaque operatur Deuos [sic] gubernando contra id quod creando fixum ratumque habuit. Gubernatio Dei: Generale super omnia; Speciale super creaturas rationales. Gubernationis duplex modus: Qui fuisset si creatura libera non exorbitasset; Qui nunc est cum exorbitarit."

39. See, for example, Aquinas's discussion of the definition of Natural Law in The treatise on Law, ed. R.J. Henle, Q.94, art. 1, pp. 235-241; also, Cicero, De Legibus, i.4, ed. C.W. Keyes, p. 317: ". . . lex est ratio summa insita in natura, quae jubet ea, quae facienda sunt, prohibetque contraria. Eadem ratio cum est hominis mente confirmata et confecta, lex est. [Law is the highest reason, implanted in Nature, which commands what ought to be done and forbids the opposite. This reason, when firmly fixed and fully developed in the human mind, is Law.]," quoted in Commentary, FLE 6(I), 477. Finally, Gratian, Decretum, Part I, Distinct. 1, in A.L. Richter and A. Friedberg, Corpus juris canonici, I (Leipzig, 1879), 2: "Natural Law is that which is contained in the Law and the Gospel whereby everyone is commanded to do to another that which he would have done to himself." Hooker cites Gratian's definition at Lawes I.12.1;1:119.30-120.1.

40. Rom.1:32 and Luke 1:6. See Lawes VII.11.10;3:211.12. Earlier in the same passage Hooker's purpose is to justify the discourse of reason in determining the polity of the Church. See further VII.11.10;1:210.27-211.6.

41. Cp. Lawes I.16.1;1:135.11-13 and III.11.3;1:248.23-26.

42. For further examples of Hooker's employment of the neoplatonic language and logic of "procession," see Lawes I.3.2;1:65.4, I.3.4;1:67.29 and 1:68.6-8, I.5.2;1:73.5-8. At the latter he states: "Againe sith there can bee no goodnesse desired which proceedeth not from God himselfe, as from the supreme cause of all things; and every effect doth after a sort conteine, at least wise resemble the cause from which it proceedeth: all things in the worlde are saide in some sort to seeke the highest, and to covet more or lesse the participation of God himselfe." The neoplatonic logic of "procession" is aptly summarised by Proclus as follows: "every effect remains in its cause, proceeds from it, and returns to it," The Elements of Theology, ed. E.R. Dodds (Oxford: Clarendon Press, 1963), p. 38.

43. On the significance for Christian ethics of Luther's distinction between the realms of Creation and Redemption, see William H. Lazareth, 'Luther's 'Two Kingdom' Ethic Reconsidered," Christian Social Ethics in a Changing World, ed. John C. Bennett (New York: Association Press, 1966); repr. in Marburg Revisited: A Reexamination of Lutheran and Reformed Traditions, eds. Paul C. Empie and James I. McCord (Minneapolis: Augsburg Press, 1966), pp. 165-176. The latter edition is cited here.

44. See Lawes I.10.14;1:109.2-110.16 where Hooker refers to the "lawes of spirituall commerce betweene Christian nations."

45. Article I, "Of Faith in the Holy Trinity," in the Articles of Religion.

46. Lawes $1.10 .13 ; 1: 108.3-7$ : “. . those lawes of reason which (man retayning his original integritie) had bene sufficient to direct each particular person in all his affaires and duties, are not sufficient but require the accesse of other lawes, now that man and his ofspring are growne thus corrupt and sinfull."

47. Lawes I.11.5,6;1:118.11-15,119.12-15. See also A Learned Sermon on the Nature of Pride, FLE 5:341.3-9. 
48. Lawes $1.11 .4 ; 1: 114.15$. Hooker cites the Proemium of Aquinas's commentary on Aristotle's Metaphysics. See Thomas Aquinas, Metaphysicorum Aristotelis expositio in duodecim libros (Turin: Marietti, 1950), p. 6. That nature does nothing in vain is a central doctrine of Aristotle's Physics. See De Caelo, 271a34. See Comm., FLE 6(I),513.

49. The classic discussion of this predicament is found in Augustine's Confessions. See the account of the "natural weight" of the soul in Confessions XIII.ix.10,11 (Oxford: Oxford University Press, 1991). 